9. Делян С.П. Дослідження вмісту флавоноїдів в листі осоту жовтого.Сучасні аспекти медицини та фармації. 2014. С. 168-169.

10. Мелікян С.М. Розробка методики кількісного визначення енрофлоксацину та ципрофлоксацину у сироватці крові курчат із використанням високоефективної рідинної хроматографії з флуорометричним детектуванням. Науково-технічний бюлетень Державного науководослідного контрольного інституту ветеринарних препаратів та кормових добавок і Інституту біології тварин. 2020. 21(2). С. 110-117.

11. Тихонов О.І., Ковальова О.О., Руденко М.В. Використання методу високоефективної рідинної хроматографії для кількісного визначення ципрофлоксацину гідрохлориду у ветеринарному препараті. Фармацевтичний журнал. 2009. № 1. С. 76-80

12. Вронська Л.В. Хроматографічний профіль гідроксикоричних кислот сухого екстракту пагонів чорниці. Фармацевтичний часопис. 2019. № 4. C. 5-14.

DOI https://doi.org/10.30525/978-9934-26-182-4-30

\title{
CONCEPT OF DRUG PSYCHOLOGY AS A NEW DIRECTION OF CLINICAL PHARMACY
}

\author{
Zimenkovsky A. B. \\ Doctor of Medical Sciences, Professor, \\ Head of the Department of Health Care Management, \\ Pharmacotherapy and Clinical Pharmacy \\ Danylo Halytsky Lviv National Medical University
}

Sekh M. Ya.

Candidate of Pharmaceutical Sciences, Assistant professor at the Department of Health Care Management, Pharmacotherapy and Clinical Pharmacy Danylo Halytsky Lviv National Medical University Lviv, Ukraine

The recent advances in medicine in general and pharmacology in particular have led to a completely new paradigm of treatment [1]. The goal of the "new age" pharmacotherapy is to transform the modern patient from a passive drug recipient to a conscious active participant with a key role in their own treatment 112 
[2]. Since the time of Hippocrates, there has been a problem of the patients' behavior towards drugs (drug behavior - term proposed by A.B. Zimenkovsky, 2014) [3], as well as that of physicians and pharmacists, relatives of the patient and the general population in this perspective. First of all, it is necessary to outline the margins of the problem, its consequences and dangers, to explore the existing methods of influencing drug behavior, for human safety and to improve the quality of pharmacotherapy and, consequently, the quality of life. The next step is to identify the field of science in which the issues should be defined, as well as to establish key, conceptual components that will underlie the new direction.

Aim of the study is to determine the theoretical principles and main components of the concept of drug psychology first proposed as a new direction of clinical pharmacy.

Materials and methods. We have used such methods as system and comparative analysis, bibliographic, bibliosemantic, modeling, analytical, content analysis. We have searched for the sources in scientometric databases PubMed, Medline, Embase, Psychinfo by the following keywords: adherence, compliance, non-adherence, compliance with treatment, patients' behavior regarding drugs, refusal of pharmacotherapy. The search focused on metaanalyzes, systematic reviews and reviews of relevant information flows over the last 20 years (from January 2000 to January 2020). Based on the analysis and generalization of relevant scientific literature, the need for the formation of the concept of drug psychology as a new direction of clinical pharmacy is substantiated.

Results of the study. Human behavior is studied mainly by psychology and sociology. We believe that human drug behavior should be the object of study of drug psychology (the term is introduced for the first time) [4]. We have developed the concept of drug psychology for the first time. The methodology of its research is substantiated. We have highlighted a set of methods and tools for influencing drug psychology and drug behavior, changes in their irrational component, assessment of changes in drug psychology and drug behavior of the patient. The principles of research organization are offered. The priority directions necessary for carrying out the further researches, including for the purpose of diagnostics of drug psychology and forecasting of medical behavior of the patient and improvement of medical behavior of the doctor and the pharmacist are outlined.

Like any new direction, drug psychology and drug behavior involves the formation of a theoretical basis, which includes partially existing and new terminology for the reflection and formation of new technologies and practices. 
Therefore, we have developed a new glossary of newly formed terms $(\mathrm{n}=84)$ with their author's interpretation.

Conclusions: 1 . The result of our study was the creation of the concept of drug psychology as a new direction of clinical pharmacy with a scientific justification of its main components, the outlining of existing components and those that require additional study and implementation. We have identified drug behavior as the main object of research in drug psychology. 2. A new glossary of terms proposed for the first time $(n=84)$ has been developed, which we consider to be the theoretical basis for the formation of a new direction of medicine and clinical pharmacy - drug psychology.

\section{References:}

1. Kardas P. et al (2013). Determinants of patient adherence: a review of systematic reviews. Front Pharmacol. 2013. 25;4:91. doi: 10.3389/fphar.2013.00091. PMID: 23898295; PMCID: PMC3722478.

2. Bilger M, et al (2019). Using Adherence-Contingent Rebates on Chronic Disease Treatment Costs to Promote Medication Adherence: Results from a Randomized Controlled Trial. Appl Health Econ Health Policy. 2019 ec;17(6):841-855. doi: 10.1007/s40258-019-00497-0.

3. Зіменковський А.Б. et al (2014). Трактування дефініцій комплаєнсу та адгеренсу як складових лікової поведінки пацієнта. Клінічна фармація, фармакотерапія та медична стандартизація, №3-4. С. 121-129

4. Зіменковський А. (2021) Лікова психологія / А. Зіменковський. Львів: Видавництво «Світ», 2021. 312 с 